\title{
Pengaruh ketimpangan pendapatan terhadap kemiskinan di Provinsi Kepulauan Bangka Belitung tahun 2009-2018
}

\author{
Khoirun Nisa1, Ayu Wulandari*1, \& Rini Luciani Rahayu ${ }^{2}$ \\ 1 Fakultas Ekonomi, Universitas Bangka Belitung, Indonesia \\ 2Badan Pusat Statisik Kabupaten Bangka, Indonesia
}

\begin{abstract}
Abstrak: Penelitian ini bertujuan untuk mengetahui pengaruh ketimpangan pendapatan terhadap kemiskinan di Provinsi Kepulauan Bangka Belitung tahun 2009-2018. Variabel dependen dalam penelitian ini adalah kemiskinan dan variabel Independen adalah ketimpangan pendapatan. Penelitian ini menggunakan pendekatan kuantitatif. Data yang digunakan adalah data times series dari tahun 2009 sampai Tahun 2018 di Provinsi Kepulauan Bangka Belitung. Teknik Analisis data dalam penelitian ini menggunakan analisis regresi linier sederhana. Hasil penelitian menunjukkan bahwa ketimpangan pendapatan berpengaruh signifikan dan negatif terhadap kemiskinan di Provinsi Kepulauan Bangka Belitung.
\end{abstract}

Katakunci: ketimpangan pendapatan; kemiskinan; regresi linier sederhana

\begin{abstract}
This study aims to determine the effect of income inequality on poverty in the Bangka Belitung Islands Province in 2009-2018. Bangka Belitung Province is one of several provinces in Indonesia which is dealing with poverty problem. The dependent variable in this study is poverty and the independent variable is income inequality. This study uses a quantitative approach. The data used are Times Series data from 2009 to 2018 in the Bangka Belitung Islands Province. Data analysis techniques in this study used simple linear regression analysis. The results showed that income inequality had a significant and negative effect on poverty in the Bangka Belitung Islands Province. The poverty rate shows an increasing trend and the Gini ratio shows a trend that tends to increase.
\end{abstract}

Keywords: income inequality; poverty; simple data regression

JEL Classification: Co1; D63;I32 


\section{PENDAHULUAN}

Kemiskinan merupakan sutu masalah yang selalu dihadapi manusia yang sama tuanya dengan usia kemunusiaan itu sendiri. Impilkasi permasalahan kemiskinan dapat melibatkan berbagai segi kehidupan manusia. Dengan kata lain bahwa kemiskinan ini merupakan masalah sosial yang sifatnya mendunia, artinya masalah kemiskinan sudah menjadi perhatian dunia, dan masalah tersebut ada di semua negara, walaupun dampak dari kemiskinan beragam (Nurwati, 2008). Kemiskinan terjadi karena kemampuan masyarakat sebagai pelaku ekonomi tidak sama, sehingga terdapat masyarakat yang tidak dapat ikut serta dalam proses pembangunan (Nasir, 2008; Widayatsari, 2016). Kemakmuran negara tidak sematamata didasarkan pada tolak ukur besarnya pendapatan nasional dan pendapatan per kapita saja, namun juga bagaimana pendapatan nasional itu didistribusikan, apakah pendapatan nasional didistribusikan secara lebih merata atau timpang (Abdullah, 2013).

Provinsi Kepulauan Bangka Belitung merupakan salah satu provinsi di Indonesia dengan permasalahan yang dihadapi pemerintahnya tidak terlepas dari upaya untuk mengatasi dan memberantas tingkat kemiskinan walaupun provinsi ini berada pada peringkat ke-5 kemiskinan terendah dan memiliki tingkat ketimpangan pendapatan terendah se-Indonesia. Tahun 2018 tingkat kemiskinan menurun di semua provinsi kecuali di beberapa provinsi yang salah satunya adalah Provinsi Kepulauan Bangka Belitung. Walaupun Provinsi Kepulauan Bangka Belitung merupakan salah satu provinsi dengan ketimpangan yang rendah tetapi belum tentu Provinsi ini bisa terlepas dari permasalahan kemiskinan. Kondisi kemiskinan Provinsi Kepulauan Bangka Belitung Tahun 2009-2018 dapat dilihat pada Tabel 1.

Tabel 1. Kondisi Kemiskinan Provinsi Kepulauan Bangka Belitung Tahun 2009-2018

\begin{tabular}{ccccc}
\hline Tahun & $\begin{array}{c}\text { Garis } \\
\text { Kemiskinan }\end{array}$ & $\begin{array}{c}\text { Jumlah } \\
\text { Penduduk }\end{array}$ & $\begin{array}{c}\text { Jumlah Penduduk } \\
\text { Miskin }\end{array}$ & $\begin{array}{c}\text { Persentase } \\
\text { Penduduk Miskin }\end{array}$ \\
\hline 2009 & 280.862 & 1.189 .669 & 76.010 & 7,37 \\
2010 & 315.556 & 1.230 .227 & 67.750 & 6,51 \\
2011 & 323.638 & 1.258 .234 & 65.550 & 5,16 \\
2012 & 382.412 & 1.286 .551 & 70.200 & 5,37 \\
2013 & 427.081 & 1.315 .123 & 69.400 & 5,25 \\
2014 & 469.814 & 1.343 .881 & 67.200 & 4,97 \\
2015 & 488.701 & 1.372 .813 & 74.090 & 5,40 \\
2016 & 534.229 & 1.401 .827 & 72.760 & 5,22 \\
2017 & 587.530 & 1.430 .865 & 74.090 & 5,20 \\
2018 & 631.647 & 1.459 .873 & 76.260 & 5,25 \\
\hline
\end{tabular}

Sumber: Badan Pusat Statistik Provinsi Kepulauan Bangka Belitung (2019)

Dari Tabel 1 mengenai Kondisi Kemiskinan Provinsi Kepulauan Bangka Belitung Tahun 2009-2018 terlihat bahwa jumlah penduduk miskin cenderung mengalami peningkatan setiap tahunnya. Jumlah penduduk miskin tertinggi berada pada tahun 2009 yaitu sebanyak 76.010 orang. Jumlah penduduk miskin terendah berada pada tahun 2011 yaitu sebesar 65.550 orang. Jumlah penduduk miskin yang setiap tahunnya cenderung bertambah tidak terlepas dari pengaruh tingginya garis kemiskinan di Provinsi Kepulauan Bangka Belitung. Faktor utama penyebab 
tingginya garis kemiskinan Provinsi Kepulauan Bangka Belitung berasal dari komponen pada garis kemiskinan komoditi makanan (GMK) yang memberi kontribusi sebesar 72,59 persen. Tingginya rata-rata pengeluaran per kapita masyarakat untuk membeli komoditas makanan dikarenakan tingginya tingkat inflasi di Provinsi Kepulauan Bangka Belitung yang mendorong kenaikan garis kemiskinan secara keseluruhan (Kantor Wilayah Ditjen Perbendaharaan Provinsi Bangka Belitung, 2019).

Penyebab utama kemiskinan suatu rumah tangga adalah rendahnya pendapatan yang mereka terima (Rahayu et al., 2013; Hidir \& Jonyanis, 2017). Sebagian besar keluarga miskin memiliki jumlah anggota keluarga yang banyak sehingga kondisi perekonomian mereka yang berada di garis kemiskinan semakin memburuk seiring dengan memburuknya ketimpangan pendapatan atau kesejahteraan (Todaro \& Smith, 2006).

Hubungan antara kesenjangan dan kemiskinan sebagai hubungan yang pragmatis, yaitu bahwa kesenjangan menyebabkan kemiskinan semakin parah atau kesenjangan adalah bentuk dari kemiskinan (Sugiyarto et al, 2015). Dalam mengukur ketimpangan pendapatan dapat menggunakan gini ratio. Nilai ketidakmerataan terletak antara 0 (kemerataan sempurna) sampai 1 (ketidakmerataan sempurna). Koefisien gini ketidakmerataan sedang berkisar antara 0,36-0,49, ketidakmerataan tinggi berkisar 0,50-0,70 dan ketidakmerataan rendah berkisar antara 0,20-0,35 (Arsyad, 2010).

Tabel 2. Gini ratio Provinsi Kepulauan Bangka Belitung tahun 2009-2018

\begin{tabular}{cc}
\hline Tahun & Gini ratio \\
\hline 2009 & 0.29 \\
2010 & 0.30 \\
2011 & 0.30 \\
2012 & 0.31 \\
2013 & 0.30 \\
2014 & 0.30 \\
2015 & 0.28 \\
2016 & 0.28 \\
2017 & 0.28 \\
2018 & 0.28
\end{tabular}

Sumber: Badan Pusat Statistik Provinsi Kepulauan Bangka Belitung (2019)

Berdasarkan Tabel 2 mengenai gini ratio Provinsi Kepulauan Bangka Belitung Tahun 2009-2018 dapat terlihat bahwa gini ratio di Provinsi Kepulauan Bangka Belitung ini tergolong rendah. Gini ratio tertinggi terjadi pada Tahun 2012. Tahuntahun berikutnya gini ratio di Kepulauan Bangka Belitung mulai menurun hingga pada angka 0,28. Tercatat di Badan Pusat Statistik bahwa Provinsi Kepulauan Bangka Belitung memiliki gini ratio paling rendah diantara provinsi-provinsi lainnya di Indonesia. 


\section{METODE}

Jenis penelitian yang digunakan dalam penelitian ini adalah penelitian kuantitatif. Penelitian kuantitatif untuk menyelidiki, menemukan, menggambarkan, dan menjelaskan kualitas atau keistimewaan dari pengaruh sosial yang tidak dapat diukur atau digambarkan melalui pendekatan kualitatif (Sugiyono, 2016). Jenis data dalam Penelitian ini menggunakan data sekunder. Data ini diperoleh dengan menggunakan studi literatur yang dilakukan terhadap banyak buku yang diperoleh berdasarkan catatan-catatan yang berhubungan dengan penelitian. Penelitian ini menggunakan data yang dari Badan Pusat Statistik Provinsi Kepulauan Bangka Belitung.

\section{Data Sekunder}

Dalam penelitian ini menggunakan data sekunder, yaitu data rasio gini di Provinsi Kepulauan Bangka Belitung periode 2009-2018 dan data jumlah penduduk miskin di Provinsi Kepulauan Bangka Belitung periode 2009-2018.

\section{Analisis Data}

Teknik analisis data yang digunakan untuk mengetahui pengaruh ekonomi terhadap distribusi pendapatan menggunakan model ekonometrik dengan persamaan regresi linier sederhana. Teknik analisis data yang digunakan dalam penelitian ini adalah teknik analisis data kuantitatif, yaitu dengan menggunakan data-data yang terdapat dalam website BPS Provinsi Kepulauan Bangka mengenai kondisi perekonomian di Provinsi Kepulauan Bangka Belitung berupa data tingkat kemiskinan dan ketimpangan pendapatan. Setelah pengumpulan data, selanjutnya data diproses menggunakan software pengolah data SPSS dengan metode regresi linier sederhana untuk selanjutnya hasil dari pengolahan data akan dianalisis.

\section{Kerangka Berpikir}

Kerangka berpikir model konseptual tentang bagaimana teori berhubungan dengan berbagai faktor yang telah di identifikasi sebagai masalah yang penting (Sugiyono, 2016). Adapun gambaran kerangka berpikir pada penelitian ini tertera pada Gambar 1.

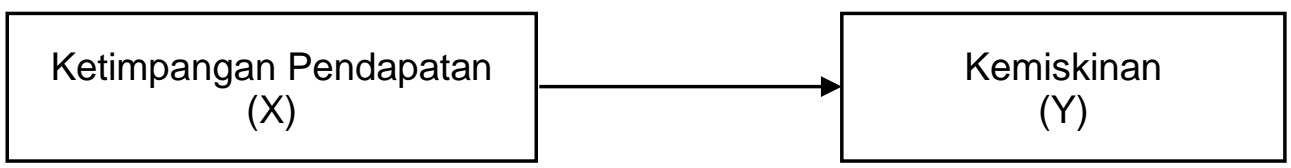

Gambar 1. Kerangka Pemikiran

Hipotesis yang dikembangkan dalam penelitian ini adalah sebagai berikut:

$\mathrm{HO}$ : Ketimpangan Pendapatan $(\mathrm{X})$ tidak berpengaruh terhadap kemiskinan $(\mathrm{Y})$

$\mathrm{H} 1$ : Ketimpangan Pendapatan $(\mathrm{X})$ berpengaruh terhadap kemiskinan $(\mathrm{Y})$ 


\section{HASIL DAN PEMBAHASAN}

\section{Analisis Kemiskinan}

Jumlah penduduk miskin yang merupakan penduduk dengan pengeluaran per kapita per bulan di bawah garis kemiskinan cenderung mengalami peningkatan setiap tahunnya. Jumlah penduduk miskin tertinggi berada pada tahun 2009 yaitu sebanyak 76.010 orang. Jumlah penduduk miskin terendah berada pada tahun 2011 yaitu sebesar 65.550 orang. Penyebab jumlah penduduk miskin mengalami peningkatan pada Tahun 2018 adalah karena tingginya garis kemiskinan akibat tingginya tingkat inflasi. Tingkat inflasi yang tinggi mempengaruhi tingginya hargaharga kebutuhan pokok sehingga pengeluaran masyarakat menjadi semakin besar. Sementara itu pendapatan masyarakat belum mampu untuk menutupi jumlah pengeluarannya. Penyebab turunnya Jumlah penduduk miskin didorong oleh upah minimum provinsi, pertumbuhan PDRB sektor industri dan pertanian serta penurunan tingkat pengangguran. Fluktuasi jumlah penduduk miskin di Provinsi Kepulauan Bangka Belitung dapat dilihat pada Gambar 2.

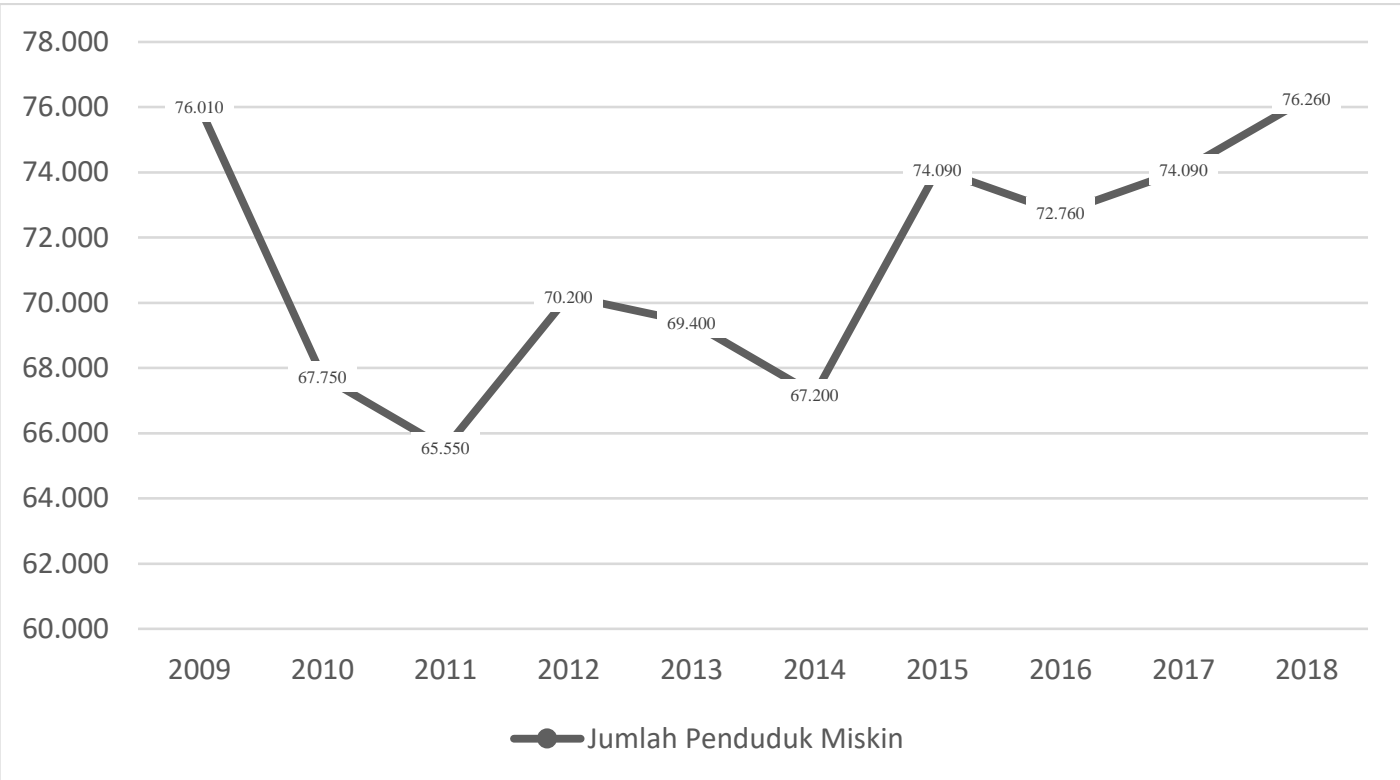

Sumber: Badan Pusat Statistik Provinsi Kepulauan Bangka Belitung (2019)

Gambar 2. Jumlah Penduduk Miskin di Provinsi Kepulauan Bangka Belitung

\section{Analisis Ketimpangan Pendapatan}

Pada Gambar 3 terlihat bahwa gini ratio di Provinsi Kepulauan Bangka Belitung cenderung menurun setiap tahunnya. Gini ratio adalah indeks yang paling penting untuk mengukur atau memperkirakan ketimpangan pendapatan (Chen et al., 2014). Gini ratio terendah berada pada tahun 2015 sampai dengan tahun 2018 yaitu sebesar 0,28 dan tertinggi terjadi pada tahun 2012 yaitu sebesar 0,31. September 2018, gini ratio di Provinsi Kepulauan Bangka Belitung adalah yang terendah seIndonesia. Hal ini menandakan bahwa jurang kesenjangan antara penduduk miskin dan penduduk kaya semakin menurun dan menunjukkan bahwa tingkat pemerataan ekonomi cukup baik di Provinsi Kepulauan Bangka Belitung. 


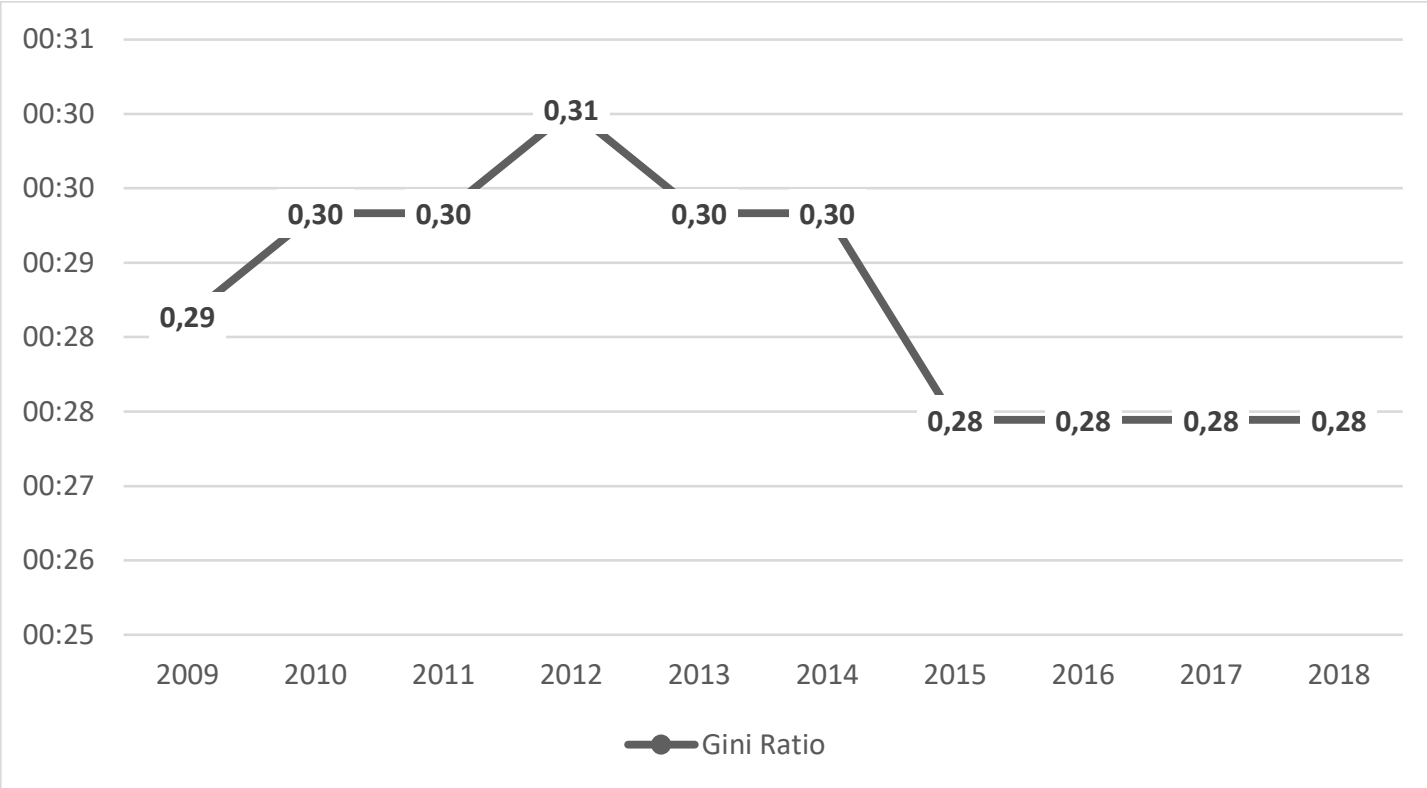

Sumber: Badan Pusat Statistik Provinsi Kepulauan Bangka Belitung (2019)

Gambar 3. Gini ratio Provinsi Kepulauan Bangka Belitung

Upaya yang dilakukan Pemprov untuk pemerataan ekonomi tersebut adalah dengan memberdayakan kemampuan ekonomi lokal dari masyarakat, seperti memajukan warung-warung ketimbang jaringan waralaba. Peningkatan Usaha Mikro Kecil Menengah (UMKM) di Provinsi Kepulauan Bangka Belitung terus dikembangkan dan ditingkatkan.

\section{Hasil Uji Regresi Linier Sederhana}

Berdasarkan hasil uji regresi linier sederhana pengaruh ketimpangan pendapatan terhadap kemiskinan di Provinsi Kepulauan Bangka Belitung yang dilakukan maka didapatkan hasil seperti pada Tabel 3.

Tabel 3. Hasil Uji koefisien Regresi

\begin{tabular}{lccrrrr}
\hline \multirow{2}{*}{ Model } & $\begin{array}{c}\text { Unstandardized } \\
\text { Coofficient }\end{array}$ & $\begin{array}{c}\text { Strandardized } \\
\text { Coefficents }\end{array}$ & $\begin{array}{c}\text { Standard } \\
\text { Coefficients }\end{array}$ & \multirow{2}{*}{ T } & \multirow{2}{*}{ Sig. } \\
\cline { 2 - 4 } & \multicolumn{1}{c}{$\mathrm{B}$} & Std.Error & Beta & & \\
\hline (Constant) & 145745,690 & 22786,268 & & 6,396 &, 000 \\
Ketimpangan & $-254844,828$ & 77982,136 &,- 756 & $-3,268$ &, 011 \\
Pendapatan & & & & & \\
\hline
\end{tabular}

Berdasarkan Tabel 3 dapat dilihat bahwa nilai konstanta sebesar 145745,690 sedangkan hasil nilai keofisien regresi ketimpangan pendapatan sebesar 254844,828 . Dengan demikian dapat dibuat persamaan regresi yang akan dianalisis adalah sebagai berikut:

$$
Y=145745,690-254844,828 X
$$

Berdasarkan persamaan regresi tersebut, dapat dilihat bahwa nilai konstanta sebesar 145745,690 menyatakan bahwa jika nilai $X=0$ atau variabel ketimpangan 
pendapatan tidak ada, maka nilai kemiskinan adalah sebesar 145745,690 . Koefisien regresi variabel ketimpangan pendapatan 254844,828 , mengandung arti bahwa setiap penambahan satu poin variabel ketimpangan pendapatan, maka hal itu akan menurunkan kemiskinan sebesar 254844,828 kali.

\section{Uji Koefisien Regresi (Uji t)}

Dari hasil pengolahan data dapat dilihat bahwa ketimpangan pendapatan memiliki signifikansi sebesar 0,011<0,05. Jika dibandingkan pada t-tabel berarti thitung > t-tabel $(-3,268>2,306)$. Hal ini menandakan bahwa variabel ketimpangan pendapatan berpengaruh negatif dan signifikan terhadap kemiskinan di Provinsi Kepulauan Bangka Belitung.

Provinsi Kepulauan Bangka Belitung mempunyai angka gini ratio yang rendah tetapi jumlah penduduk miskinnya masih relatif tinggi. Tahun 2018 gini ratio sebesar 0,28 persen sementara itu jumlah penduduk miskin sebanyak 76.260 orang. Gini ratio yang rendah menandakan bahwa tingkat pendapatan dan pengeluaran penduduk baik dari golongan atas maupun golongan bawah tidak jauh berbeda atau hampir sama. Upaya yang telah dilakukan Pemprov Kepulauan Bangka Belitung untuk pemerataan ekonomi adalah dengan memberdayakan kemampuan ekonomi lokal dari masyarakat, seperti memajukan Usaha Mikro Kecil dan Menegah (UMKM) dibandingkan jaringan waralaba. Hal ini dilakukan pemerintah dalam rangka untuk meningkatkan pendapatan masyarakat golongan bawah. Sehingga pendapatan masyarakat golongan bawah di Provinsi Kepulauan Bangka Belitung dapat terbantu. Tetapi cara ini belum mampu untuk mengurangi jumlah penduduk miskin di Provinsi Kepulauan Bangka Belitung. Pendapatan yang didapatkan penduduk Provinsi Kepulauan Bangka Belitung belum mencukupi untuk memenuhi kebutuhan mereka. Penyebabnya adalah karena rata-rata pengeluaran per kapita penduduk yang masih berada di bawah garis kemiskinan. Hal ini disebabkan karena tingginya tingkat inflasi yang menyebabkan harga-harga kebutuhan dasar di Provinsi Kepulauan Bangka Belitung naik serta turunnya pendapatan masyarakat yang bekerja pada sektor informal karena murahnya harga lada atau pembatasan pertambangan timah.

\section{Uji Koefisien determinasi $\left(\mathbf{R}^{2}\right)$}

Koefisien determinasi $\left(R^{2}\right)$ digunakan untuk mengukur persentase total variasi variabel dependen yang dapat dijelaskan oleh variabel independen dalam model (Kuncoro, 2013). Besarnya nilai $R$ Square yang diperoleh sebesar 0,572 menunjukkan bahwa proporsi pengaruh variabel ketimpangan pendapatan terhadap kemiskinan sebesar 57,2 persen. Artinya sebanyak 57,2 persen ketimpangan pendapatan mampu menjelaskan variabel kemiskinan, sedangkan sisanya 43 persen dipengaruhi oleh variabel lain, misalnya pengangguran, pertumbuhan ekonomi, upah minimum dan tingkat pendidikan. 


\section{KESIMPULAN}

Berdasarkan hasil penelitian yang dilakukan tentang pengaruh ketimpangan pendapatan terhadap kemiskinan di Provinsi Kepulauan Bangka Belitung Tahun 2009-2018, dapat simpulkan bahwa ketimpangan pendapatan berpengaruh negatif dan signifikan terhadap tingkat kemiskinan di Provinsi Kepulauan Bangka Belitung.

Menurut data yang didapatkan dari BPS, Provinsi Kepulauan Bangka Belitung memiliki angka gini ratio yang rendah dan tingkat kemiskinan yang relatif tinggi. Penyebabnya adalah karena program bantuan pemberian modal kepada penduduk Provinsi Kepulauan Bangka Belitung untuk menjalankan UMKM dapat membantu perekonomian penduduknya sehingga pendapatan masyarakat jadi meningkat dan menciptakan pemerataan. Tetapi hal ini tidak berdampak pada kesejahteraan masyarakatnya. Pendapatan penduduk Provinsi Kepulauan Bangka Belitung masih tergolong rendah dan belum mencukupi untuk memenuhi kebutuhan dasar mereka. Hal ini dapat disebabkan karena tingginya tingkat inflasi di Provinsi Kepulauan Bangka Belitung yang menyebabkan harga-harga kebutuhan pokok meningkat. Faktor lain yang mempengaruhi naiknya tingkat kemiskinan juga disebabkan karena produksi pertambangan yang menurun karena banyaknya usaha penambangan timah yang ditutup dan turunnya harga produk perkebunan seperti lada dan karet.

\section{DAFTAR PUSTAKA}

(1) Abdullah, R. (2013). Faktor-faktor Yang Mempengaruhi Ketimpangan Pendapatan di Jawa Tengah. JEJAK: Jurnal Ekonomi dan Kebijakan, 6(1), 42-53. https://doi.org/10.15294/jejak.v6i1.3747

(2) Arsyad, L. (2010). Ekonomi Pembangunan Edisi ke-5. Yogyakarta, Indonesia: STIEM YKPN.

(3) Badan Pusat Statistik Kabupaten Bangka. (2019, June 20). https://bangkakab.bps.go.id/

(4) Badan Pusat Statistik Provinsi Kepulauan Bangka Belitung. (2019, June 20). https://babel.bps.go.id/

(5) Badan Pusat Statistik. (2019, June 20). Indikator Sosial Provinsi Kepulauan Bangka Belitung 2018. Bangka Belitung, Indonesia: Badan Pusat Statistik Provinsi Kepulauan Bangka Belitung.

(6) Chen, J., Yaqing, S., Fengying, L., \& Zhao, A. (2014). An Analysis of Relationship among Income Inequality, Poverty, and Income Mobility, Based on Distribution Functions, 2014, 1-10. https://doi.org/10.1155/2014/186564

(7) Hidir, A., \& Jonyanis. (2017). Poverty Alleviation Model of "Laut" Tribe and Structure of Economy in Indragiri Hilir Regency, Riau Province. International Journal of Economics, Business and Applications, 2(1), 65-75. https://ijeba.ejournal.unri.ac.id/index.php/lJEBA/article/view/4651

(8) Kantor Wilayah Ditjen Perbendaharaan Provinsi Bangka Belitung. (2019). Kajian Fiskal Regional Provinsi Kepulauan Bangka Belitung Tahun 2018. Bangka Belitung, Indonesia: Kantor Wilayah Ditjen Perbendaharaan Provinsi Bangka Belitung.

(9) Kuncoro, M. (2013). Mudah Memahami dan Menganalisis Indikator Ekonomi. Yogyakarta, Indonesia: UPP STIM YKPN Yogyakarta.

(10) Nasir, M. (2008). Metode Penelitian. Jakarta, Indonesia: Ghalia. 
(11) Nurwati, Nunung. (2008). Kemiskinan : Model Pengukuran, Permasalahan dan Alternatif Kebijakan. Jurnal Kependudukan Padjadjaran, 10(1), 1-11. http://journal.unpad.ac.id/kependudukan/article/view/doc1

(12) Rahayu, S., Darus, H.M.B., \& Hasyim, H. (2013). Analisis Tingkat Ketimpangan Pendapatan dan Kemiskinan Petani Padi (Studi Kasus: Desa Sidodadi Ramunia, Kecamatan Beringin, Kabupaten Deli Serdang). Jurnal on Social Economic of Agriculture and Agribusiness, 2(10). https://jurnal.usu.ac.id/index.php/ceress/article/view/8019

(13) Sugiyarto., Mulyo, JH., Seleky, RN. (2015). Kemiskinan Dan Ketimpangan Pendapatan Rumah Tangga Di Kabupaten Bojonegoro. Agro Ekonomi. 26(02), 115120. https://doi.org/10.22146/agroekonomi.17264

(14) Sugiyono. (2016). Metode Penelitian Kuantitatif Kualitatif dan R\&D. Bandung, Indonesia: PT Alfabeta.

(15) Todaro, M.P., \& Smith, S.C. (2006). Pembangunan Ekonomi. Jakarta, Indonesia: Erlangga.

(16) Widayatsari, A. (2016). Socio-Cultural Factors towards Poverty in the Regency Gunung Kidul Daerah Istimewa Yogyakarta Contribution of Indonesian Islam to the World Civilization Journal of Economics and Sustainable Development, 7(20), 31-39. https://www.iiste.org/Journals/index.php/JEDS/article/view/33693 